\title{
A digital, spatial, geological model of the Miocene in Jylland, Denmark
}

\author{
Margrethe Kristensen, Thomas Vangkilde-Pedersen and Erik Skovbjerg Rasmussen
}

A major hydrogeological programme has been carried out to map the Miocene succession in central and southern Jylland (Fig. 1). The Miocene deposits comprise several aquifers with potential drinking water resources and have been investigated by drilling and acquisition of seismic data integrated with sedimentology and biostratigraphy. Scharling et al. (2009) described a 3D hydrogeological model that covers part of the onshore Danish Miocene deposits. The model was based on a sequence-stratigraphic approach and led to a better understanding of the geological architecture of the aquifers than traditional lithofacies models. Hence it was decided to establish a digital, spatial, geological model covering the entire onshore Miocene succession (Kristensen et al. 2010).

\section{Geology}

The onset of the Miocene is characterised by inversion tectonics causing a change in the depositional regime from full marine, clayey sediments to shallow-water, sand-rich, delta deposits (Rasmussen et al. 2010). During the Early - early Middle Miocene, regressions and transgressions were strongly controlled by eustatic sea-level changes, resulting in three phases of shoreline progradation into the basin that covers present-day Denmark. The three phases are represented by the sand-rich Billund, Bastrup and Odderup Formations, in-

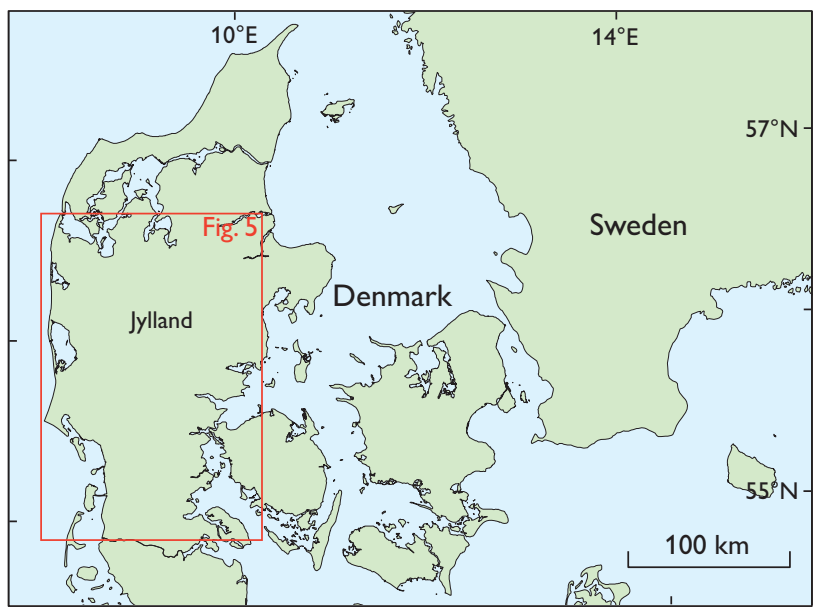

Fig. 1. Map of Denmark showing the study area in central and southern Jylland (rectangle). tercalated with the clayey and silty marine Vejle Fjord, Klintinghoved and Arnum Formations (Fig. 2). During the late Middle Miocene to the Late Miocene, the marine clay of the Hodde, Ørnhøj and Gram Formations were deposited and towards the end of the Miocene a new progradation resulted in deposition of the sandy Marbæk Formation.

\section{Sequence stratigraphic framework}

The Miocene digital, spatial, geological model is based on the sequence-stratigraphic framework of Rasmussen (2004) and Rasmussen \& Dybkjær (2005) and the lithostratigraphy of Rasmussen et al. (2010). These studies are based on new borehole data, high-resolution seismic profiles (VangkildePedersen et al. 2006) and high-resolution biostratigraphy (Dybkjær \& Piasecki 2010). In sequence stratigraphy a geological succession is divided into a succession of different lithofacies (a sequence) bounded by key-surfaces and commonly stacked in a cyclic manner. Each sequence represents

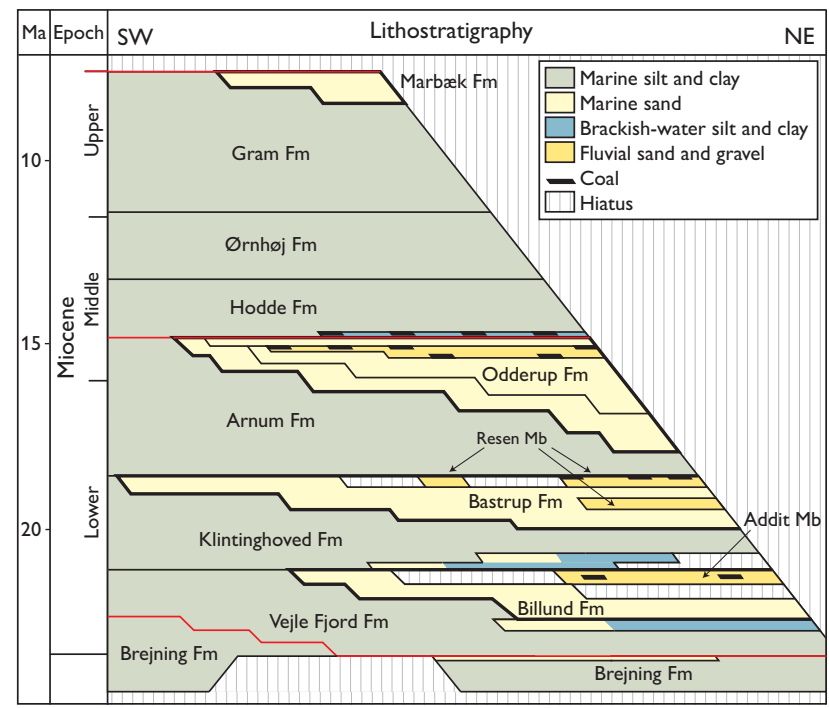

Fig. 2. Lithostratigraphic scheme of the Miocene of onshore Denmark showing the distribution of the formations from south-west to north-east Jylland. Marine deposits dominate in the south-western part of Jylland. Delta or fluvial sand deposits are mainly found in the central parts of Jylland, where they form large potential groundwater reservoirs (Rasmussen et al. 2010). 


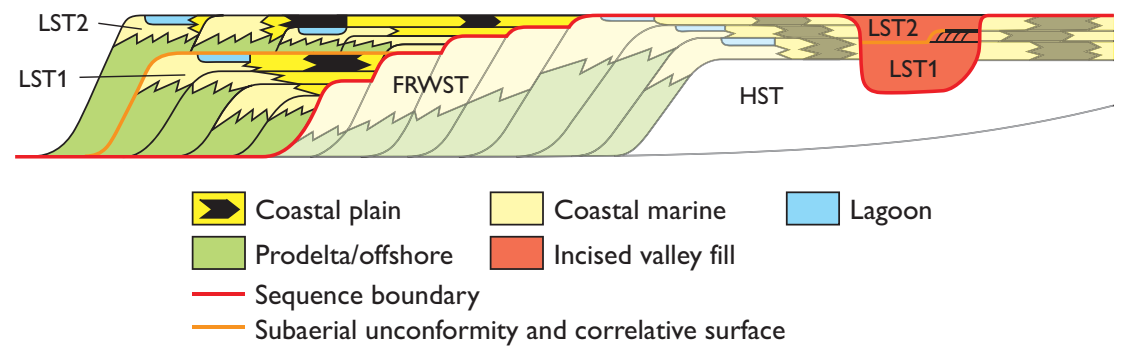

Fig. 3. A conceptual model for the development of the Miocene deposits in Jylland.

HST: Highstand systems tract, FRWST:

Forced regressive wedge systems tract. LST2: lowstand systems tract unit 2. LST1: lowstand systems tract unit 1 .

a cycle in relative sea level and can be subdivided into four systems tracts that link contemporaneous deposits together. (1) During the early stage of sea-level rise the lowstand systems tract is formed when the sediment supply from the hinterland is greater than the sea-level rise. The shoreline progrades into the basin and sands and clays are deposited in association with delta progradation. Incised valleys are filled up by fluvial deposits, which are usually dominated by coarse-grained sediments. (2) The transgressive systems tract is formed when the base-level rise outpaces the sediment supply from the hinterland, causing the shoreline to move landwards. This landward movement of the shoreline results in predominant clay and silt deposition on the former delta platform and in the basin. However, sand is still deposited along the shoreline, commonly on the shoreface and in inlets of barrier complexes, as bars in tidally influenced estuaries and in incised valleys associated with fluvial systems. (3) During the late stage of sea-level rise the highstand systems tract is formed. The sediment supply from the hinterland outpaces the sea-level rise and the shoreline again progrades into the basin. The highstand systems tract commonly shows fine- to coarser-grained deposits laid down on the slope of delta complexes or as shoreface sands alternating with lagoonal clays. (4) The forced regressive wedge systems tract is formed in the

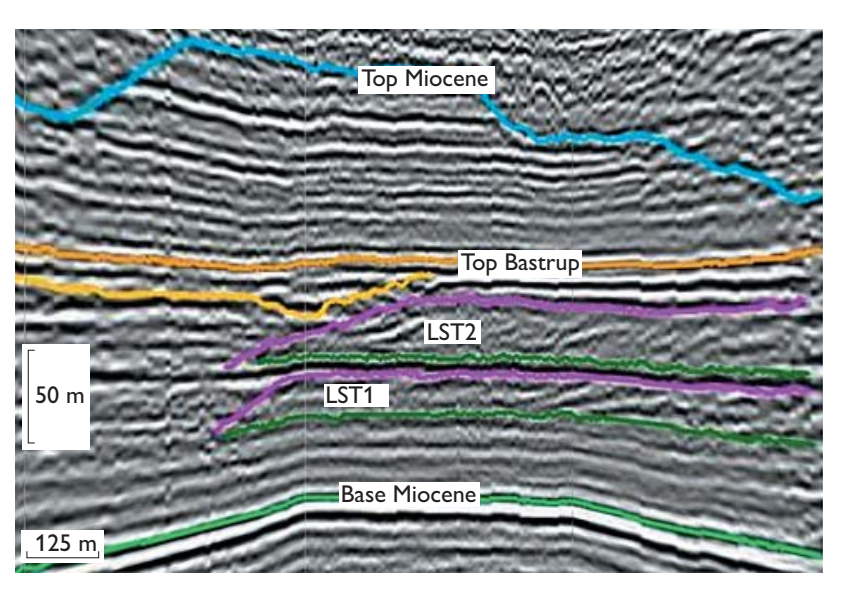

Fig. 4. Seismic profile showing two successive delta complex deposits of the lowstand systems tract of the Bastrup Formation. LST1: lowstand systems tract unit 1. LST2: lowstand systems tract unit 2. For location see Fig. 5B. marine part during falling sea level and is hence characterised by progradation of the shoreline. During falling sea level, incision commences on the highstand delta complex. The deposits are typically dominated by well-sorted, relatively coarse-grained sediments. Common deposits include different types of off-lapping shallow marine shoreface and delta deposits and deep-sea submarine fans.

In the Miocene succession of Denmark some of the best aquifers are associated with lowstand systems tracts (Fig. 3). The sand that constitutes the aquifers was partly deposited in incised valleys and partly as prograding deltas in the basinal area. The incised valleys are dominated by fluvial deposits, namely the Addit Member of the Billund Formation and the Resen Member of the Bastrup Formation (Fig. 2). Both generations show a two-fold subdivision of the valley fill that coincides with delta progradation into the basin. This pattern is, however, interrupted by minor flooding where a thin sequence of marine sand, clay and coal was deposited. An example of two such successive delta deposits from the lowstand systems tract of the Bastrup Formation is shown in Fig. 4.

The glacio-eustatic sea-level changes in the Miocene resulted in an asymmetric pattern of slow regressions and rapid transgressions, which explains why transgressive sand or clay was rarely deposited.

\section{Modelling of the Miocene succession}

The backbone of the Miocene digital, spatial, geological model is nine correlation panels (five W-E- and four S-Noriented), which constitute a conceptual geological model of the Danish Miocene (Rasmussen et al. 2010). The conceptual model is based on sedimentological investigations of samples from 150 boreholes (c. 100-400 m deep), detailed biostratigraphical studies of samples from 50 boreholes and studies of 25 outcrops tied together with a dataset of $c .1200$ $\mathrm{km}$ high-resolution seismic profiles.

With the conceptual model as the starting point, a 3D geological model has been established using the software package GeoScene 3D (www.i-gis.dk). The GeoScene 3D software gives the user direct access to carry out interpretation moving through the subsurface and better understand 3D structures. Borehole data, geophysical logs and seismic 
data have been imported to the modelling software and interpretation performed both on $2 \mathrm{D}$ profiles and in the $3 \mathrm{D}$ environment. The set-up is constructed as a layer model, but emphasis has been on distinguishing between different generations of delta lobes as the shoreline prograded into the basin during deposition of the Billund, Bastrup and Odderup Formations. Thus the model comprises 75 layers and lithological units, which have been named according to the formation and depositional environment. The top of each lithological unit is interpreted using interpretation points. The interpretation is based on data from: stratigraphically described boreholes, high-resolution seismic profiles or boreholes from the national borehole database. Free digital points have also been added to indicate the outline of deltalobes. The interpretation includes an evaluation of the quality of the points. The Top Miocene, Top Bastrup, Top Billund and Base Miocene surfaces are interpreted in almost the entire model area. Unlike these surfaces, the propagation of each generation of delta lobes, is limited and follows the position of the coastline, at the time of deposition.

On the basis of high-resolution seismic profiles and detailed lithological descriptions of borehole samples, the extension of each delta lobe has been interpreted. In Fig. 5 the maximum extension of 10 generations of delta lobes of the Bastrup Formation and 11 generations of delta lobes of the Billund Formation is shown together with the coverage of high-resolution seismic profiles and boreholes used in the sequence-stratigraphic interpretation.

To support the model, detailed interpretation of the seismic profiles shown in Fig. 5 has been conducted with focus on mapping the extent of sand-rich bodies. All previous interpretations of the Top Miocene, Top Billund, Top Ba-strup and Base Miocene have been checked, and if necessary, revised, according to the present level of knowledge. Top and bottom of sand-rich bodies in the form of delta or fluvial deposits have been interpreted on all seismic lines in order to assist the modelling work in GeoScene 3D. Internal, parallel, clinoform, reflection patterns with dips of $5-10^{\circ}$ have been interpreted as a direct indicator of fine- to coarse-grained sand, whereas sigmoidal clinoform internal reflection patterns typically indicate alternating layers of clay and sand (Rasmussen et al. 2007: Bassetti et al. 2008; Hansen \& Rasmussen 2008). Incised valleys and fluvial channels expressed by concave-up erosion surfaces are typically filled with coarse- to fine-grained sand and coarse-grained sand and gravel, respectively (Rasmussen et al. 2007). In places where the seismic data do not directly indicate sandy deposits, the profiles have nevertheless been used to extrapolate available borehole information in the best possible way.

Gamma-ray logs have been a valuable supplement to the geological descriptions of borehole samples. Most of the boreholes were drilled using the airlift drilling technique which may result in poor recovery of coarse silt and fine sand (Ditlefsen et al. 2008). Therefore, gamma-ray logs have been useful both for checking and correcting the lithological logs and as an indicator of depositional environment. Sand-rich delta units are generally coarsening upwards and are seen on the logs as upward-decreasing gamma-ray values. Fluvial channel deposits are characterised by fining-upward trends and are seen as upward-increasing gamma-ray values (Fig. 6).
Fig. 5. Map of southern and central Jylland showing the maximum extent of individual generations of delta lobes of A: Billund Formation and $\mathbf{B}$ : Bastrup Formation. The interpretation is based on high-resolution seismic profiles and data from boreholes.
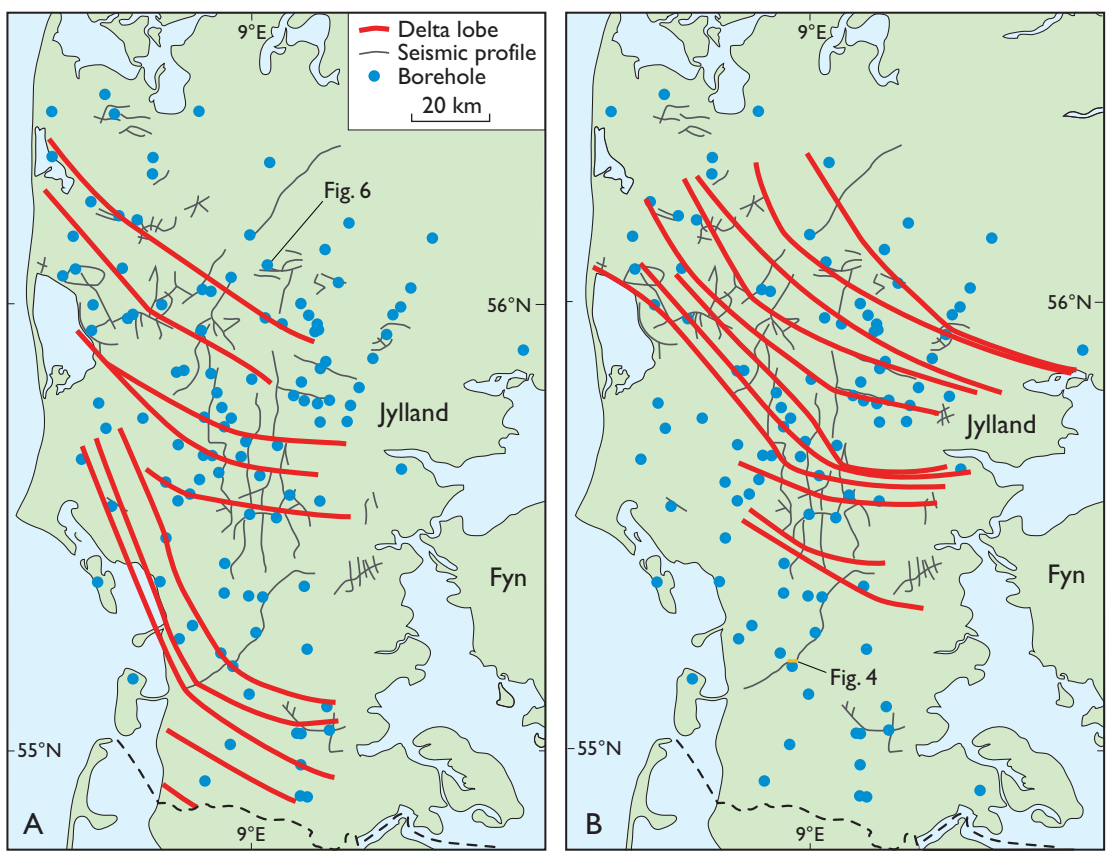


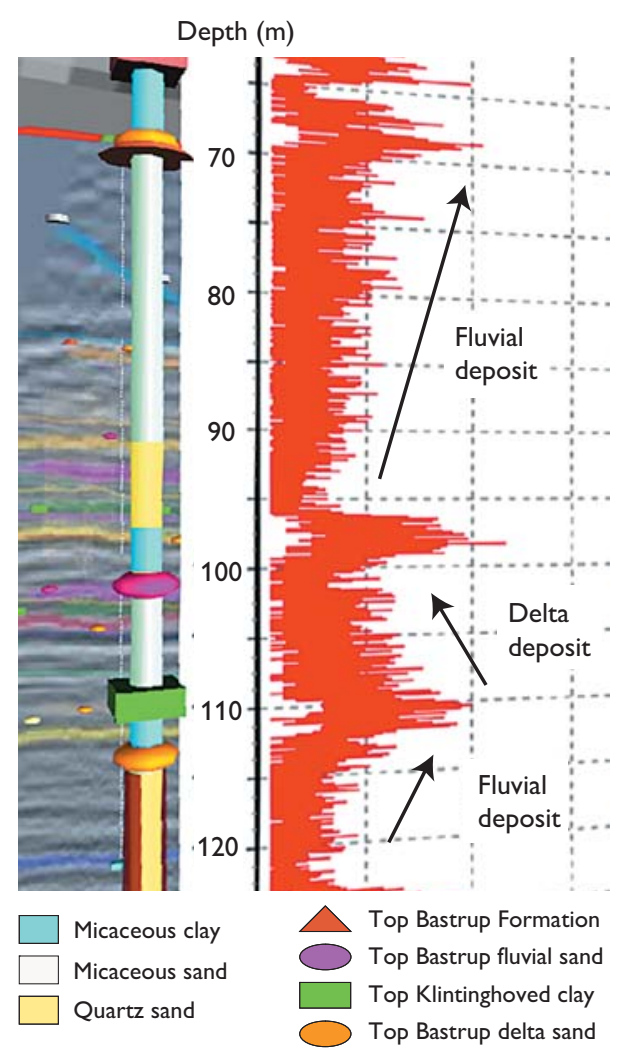

Fig. 6. Example of interpretation of depositional environment from gamma-ray $\log$ patterns. Upward-increasing gamma-ray values are interpreted as a fining-upward fluvial deposit and upward-decreasing gamma-ray values are interpreted as an upward-coarsening delta complex. For location see Fig. 5A.

\section{Future work and perspectives}

The Miocene 3D model reflects the basin development and the depositional processes as well as the palaeogeographical development during the Miocene in Denmark. The spatial, geological model is intended to serve as a geological database of lithological and stratigrafical information and can be seen as a visual archive of the geological knowledge of the Miocene in the model area. As such, it will serve as the foundation for different types of application-oriented models. The Miocene 3D model is already used in the Danish Nature Agency as a framework for at least 11 modelling projects. The model will be updated on an annual basis in the coming years as new boreholes, seismic profiles and other data become available, or following new interpretations.

\section{Acknowledgements}

The Nature Agency Centres in Ribe, Ringkøbing and Aarhus are thanked for financial support.

\section{References}

Bassetti, M.A., Berne, S., Jouet, G., Taviani, M., Dennielou, B., Flores, J.A., Gaillot, A., Gelfort, R., Lafuerza, S. \& Sultan, N. 2008: The 100-ka and rapid sea level changes recorded by prograding shelf sand bodies in the Gulf of Lions (western Mediterranean Sea). Geochemistry Geophysics Geosystems 9, Q11R05, 27 pp.

Ditlefsen, C., Sørensen, J., Pallesen, T.M., Pedersen, D., Nielsen, O.B., Christiansen, C., Hansen, B. \& Gravesen, P. 2008: Jordprøver fra grundvandsboringer, vejledning i udtagning, beskrivelse og geologisk tolkning i felten, 108 pp. Geo-vejledning 1. København: De Nationale Geologiske Undersøgelser for Danmark og Grønland.

Dybkjær, K. \& Piasecki, S. 2010: Neogene dinocyst zonation for the eastern North Sea Basin, Denmark. Review of Palaeobotany and Palynology 161, 1-29.

Hansen, J.P.V. \& Rasmussen, E.S. 2008: Structural, sedimentologic, and sea-level controls on sand distribution in a steep-clinoform asymmetric wave-influenced delta: Miocene Billund sand, eastern Danish North Sea and Jylland. Journal of Sedimentary Research 78, 130-146.

Kristensen, M., Vangkilde-Pedersen, T. \& Rasmussen, E.S. 2010: Miocæn 3D. Den rumlige geologiske model. Danmarks og Grønlands Geologiske Undersøgelse Rapport 2010/91, 46 pp.

Rasmussen, E.S. 2004: Stratigraphy and depositional evolution of the uppermost Oligocene - Miocene succession in western Denmark. Bulletin of the Geological Society of Denmark 51, 89-109.

Rasmussen, E.S. \& Dybkjær, K. 2005: Sequence stratigraphy of the Upper Oligocene - Lower Miocene of eastern Jylland, Denmark: role of structural relief and variable sediment supply in controlling sequence development. Sedimentology 52, 25-63.

Rasmussen, E.S., Vangkilde-Pedersen, T. \& Scharling, P.B. 2007: Prediction of reservoir sand in Miocene deltaic deposits in Denmark based on high-resolution seismic data. Geological Survey of Denmark and Greenland Bulletin 13, 17-20.

Rasmussen, E.S., Dybkjær, K. \& Piasecki, S. 2010: Lithostratigraphy of the Upper Oligocene - Miocene succession of Denmark. Geological Survey of Denmark and Greenland Bulletin 22, 92 pp.

Scharling, P.B., Rasmussen, E.S., Sonnenborg, T.O., Engesgaard, P. \& Hinsby, K. 2009: Three-dimensional regional-scale hydrostratigraphic modeling based on sequence stratigraphic methods: a case study of the Miocene succession in Denmark. Hydrogeology Journal 17, 1913-1933.

Vangkilde-Pedersen, T., Dahl, J.F. \& Ringgaard, J. 2006: Five years of experience with landstreamer vibroseis and comparison with conventional seismic data acquisition. Proceedings of the 19th Annual SAGEEP Symposium on the Application of Geophysics to Engineering and Environmental Problems, Seattle, USA, 1086-1093. 